\title{
PENGARUH MODEL PEMBELAJARAN KOOPERATIF TIPE TALKING CHIPS TERHADAP PENGENALAN LAMBANG BILANGAN ROMAWI PADA SISWA SEKOLAH DASAR DI KABUPATEN MAROS
}

\author{
Fathimah Az.Zahra Nasiruddin ${ }^{1 *}$ \\ ${ }^{1}$ Jurusan Pendidikan Gurus Sekolah Dasar, Fakultas Keguruan dan Ilmu Pendidikan, \\ Universitas Bosowa, Jl. Urip Sumiharjo Km.4, Gedung 2 Lantai 4, Kota Makassar, \\ Sulawesi Selatan Indonesia \\ Email : az.zahrah@universitasbosowa.ac.id
}

\begin{abstract}
ABSTRAK
Pengaruh Model Pembelajaran Kooperatif Tipe Talking Chips Terhadap Pengenalan Lambang Bilangan Romawi Pada Siswa Sekolah Dasar Di Kabupaten Maros, Fathimah Az.zahra Nasiruddin, Universitas Bosowa. Penelitian ini bertujuan untuk mengetahui pengaruh penerapan model pembelajaran kooperatif tipe talking chips terhadap pengenalan lambang bilangan romawi pada siswa sekolah dasar di Kabupaten Maros. Jenis penelitian ini adalah penelitian eksperimen dengan rancangan penelitian one-Group Pretest-Posttest. Teknik pengumpulan data yang digunkan dalam penelitian ini adalah observasi dan tes. Instrumen penelitian yang digunakan yaitu soal tes. Teknik analisis data menggunakan analisis data statistik deskriptif dan analisis statistik inferensial. Hasil penelitian ini menunjukan bahwa terdapat pengaruh yang signifikan penerapan model pembelajaran kooperatif tipe talking chips terhadap pengenalan lambang bilangan romawi pada siswa sekolah dasar di Kabupaten Maros, dibuktikan dengan hasil analisis statistik deskriptif yang menunjukan bahwa hasil belajar siswa meningkat dilihat dari nilai rata-rata posttest sebesar 72,53 serta pada hasil observasi aktivitas siswa yang menunjukan keantusiasan, keaktifan dalam bertanya dan menjawab, ketertarikan terhadap model pembelajaran, serta sikap siswa ketika belajar yang termasuk baik. Berdasarkan analisis statistik inferensial diperoleh hasil uji " $t$ " yang menunjukan nilai $t_{\text {hitung }}$ sebesar 9,78 lebih besar dari $t_{\text {tabal }}$ sebesar 2,064 pada taraf signifikasi 0,05 sehingga Hipotesis alternatif $\left(H_{\mathrm{a}}\right)$ yang menyatakan terdapat pengaruh yang signifikan penerapan model pembelajaran kooperatif tipe talking chips terhadap pengenalan lambang bilangan romawi pada siswa sekolah dasar di Kabupaten Maros.
\end{abstract}

Kata kunci: Model Pembelajaran Kooperatif, Talking Chips, Bilangan Romawi

Fakultas Keguruan dan Ilmu Pendidikan

Universitas Bosowa Makassar 


\section{PENDAHULUAN}

Dalam dunia sastra, bahasa merupakan alat utama untuk berkomunikasi Belajar adalah serangkaian kegiatan jiwa raga untuk memperoleh suatu perubahan tingkah laku sebagai hasil dari pengalaman individu dalam interaksi dengan lingkungannya yang menyangkut kognitif, afektif, dan psikomotorik. Jadi kebiasaan cara belajar juga berpengaruh pada hasil yang dinginkan. Kegiatan belajar mengajar yang baik jika guru mengetahui secara tepat faktor-faktor yang menunjang terciptanya iklim belajar mengajar. Selain itu, guru harus menguasi beberapa model, pendekatan dalam mengelola kelas atau mengatur kelas.

Saat ini guru harus memberikan pembelajaran bermakna kepada siswa, mengarahkan siswa aktif, membangun kognisi, keterampilan sehigga psikomotoriknya dapat terasah. Salah satu mata pelajaran yang turut berperan penting dalam pendidikan wawasan, keterampilan dan sikap ilmiah sejak dini bagi anak adalah mata pelajaran Matematika.

Salah satu model pembelajaan yang cocok melalui penerapan model pembelajaran talking chips akan memberikan motivasi siswa dan pengalaman siswa dalam belajar matematika. Menurut Oktaviana (2014) Dalam pelaksanaan model pembelajaran talking chips setiap anggota kelompok mendapat chips yang harus digunakan setiap kali ingin berbicara misalnya bertanya, menjawab pertanyaan, menyatakan keraguan, mengungkapkan ide, mengklarifikasi pertanyaan, mengklarifikasi ide.

Berdasarkan observasi yang telah saya lakukan sebelumnya di lokasi penelitian, proses pembelajaran masih menggunakan metode ceramah, sehingga pembelajaran masih terpusat pada guru. Pembelajaran matematika masih menekankan pada konsep-konsep yang ada didalam buku, dan belum memanfaatkan alat peraga disekitar sehinggapa proses belajar mengajar belum bisa dikatakan maksimal. Hal ini membuat pembelajaran tidak efektif, karena siswa kurang merespon terhadap pelajaran yang disampaikan, sehingga proses pembelajaran cenderung menyebabkan suasana membosankan.

Penerapan model pembelajaran talking chips akan memberikan motivasi siswa dan pengalaman siswa dalam belajar agar siswa dapat belajar dengan menyenangkan dan memperoleh manfaat besar sesuai dengan kebutuhan kurikulum, maka perlu dilakukan penelitian melalui pembelajaran model talking chips.

\section{METODE PENELITIAN}

Jenis penelitian ini adalah jenis penelitian eksperimen, yaitu suatu penelitian yang lebih menekankan analisisnya pada data numerikal (angka) yang diolah dengan metode statistika. Penelitian ini menggunakan Desain One Group Pretest and Posttest Design. Penelitian ini dilakukan selama tiga bulan yaitu semester ganjil bulan Mei 2019 sampai bulan Agustus 2019. Penentuan sampel dilakukan dengan teknik purposif random sampling yaitu penelitian memilih satu kelas untuk dijadikan kelas eksperimen. Kelas yang dipilih adalah kelas IV dengan jumlah siswa 26 orang, terdiri dari 7 siswa laki-laki, dan 19 siswa perempuan. Pada kelas IV ini, siswa diberikan tes awal sebelum siswa diberi 
perlakuan dengan menerapkan model talking chips dan setelah itu diberikan tes akhir untuk mengetahui hasil yang akan dicapai oleh siswa.Uji Instrumen penelitian dilakukan Uji Validitas tes hasil belajat menggunakan $r$ pearson, uji reliabilitas pada hasil belajar matematika menggunakan rumus reliabilitas, uji tingkat kesukaran soal, soal-soal yang dianggap baik, yaitu soal-soal sedang, adalah soal-soal yang mempunyai indeks kesukaran 0,30 sampai dengan 0,70. Dan uji daya pembeda soal adalah kemampuan sesuatu soal untuk membedakan antara siswa yang pandai (berkemampuan tinggi) dengan siswa yang kurang pandai (berkemampuan rendah). Butir-butir soal yang baik adalah butir-butir soal yang mempunyai indeks diskriminasi 0,4 sampai dengan 0,7.Analisis data yang digunakan statistik deskriptif menggunakan Rata-rata dan persentasi hasil belajar dan Analisis statistik inferensial. Dalam penggunaan statistik inferensial ini peneliti menggunakan teknik statistik $\mathrm{t}$ (uji-t), dengan tahapan sebagai berikut

$$
\mathrm{t}=\frac{M d}{\sqrt{\frac{\sum X^{2} d}{N(N-1)}}}
$$

(Arikunto, 2010:349)

Menentukan aturan pengambilan keputusan atau kriteria yang signifikan Kaidah pengujian signifikan :

(1) Jika $t_{\text {Hitung }}>t$ Tabel maka $\mathrm{H}_{\mathrm{o}}$ ditolak dan $\mathrm{H}_{1}$ diterima, berarti penggunaan metode eksperimen berpengaruh terhadap hasil belajar siswa pada mata pelajaran Matematika Lambang Bilangan Romawi kelas IV SDN 240 Baddo-Baddo Kebupaten Maros.

(2) Jika $t_{\text {Hitung }}<t_{\text {Tabel }}$ maka $\mathrm{H}_{\mathrm{o}}$ diterima, berarti penggunaan metode eksperimen tidak berpengaruh terhadap hasil belajar siswa pada materi Lambang Bilangan Romawi kelas IV SDN 240 Baddo-Baddo Kabupaten Maros. Menentukan harga $\mathrm{t}$ Tabel dengan Mencari $\mathrm{t}$ Tabel menggunakan tabel distribusi t dengan taraf signifikan $\alpha=0,05$ dan $d b=N-2$.

\section{HASIL DAN PEMBAHASAN}

\section{a. Hasil Penelitian}

Hasil penelitian yang dilakukan terhadap 26 siswa mengenai pengaruh penggunaan model pembelajaran kooperatif tipe talking chips terhadap pengenalan lambang bilangan romawi siswa kelas IV SDN 240 Badd0-Baddo, sebelum diberikan perlakuan berupa penggunaan model pembelajaran kooperatif tipe talking chips pada posttest,maka hasil yang di peroleh dapat dibandingkan. Berikut ini akan dianalisis dengan menggunakan analisis statistik deskripstif guna menggambarkan tingkat hasil belajar masing-masing perorangan. Observasi dilakukan oleh observar pada saat siswa diberikan perlakuan, serta analisis statistik inferensial untuk menguji hipotesis penelitian tentang ada atau tidaknya pngaruh penggunaan model pembelajaran kooperatif tipe talking chips terhadap pengenalan lambang bilangan romawi pada siswa. 


\section{Hasil Observasi}

Data observasi diperoleh berupa pengamatan guru dan siswa saat proses belajar mengajar.

a. Observasi Aktivitas Guru dan Siswa

Observasi dilakukan dari awal sampai akhir selama kegiatan pembelajaran berlangsung. Observasi yang dilakukan oleh teman sejawat sebagai observer, observer mencatat aktivitas guru dan siswa selama proses pembelajaran. Hasil observasi siswa yang diperoleh peneliti menunjukan bahwa ketika berkelompok terdapat siswa yang tidak fokus dengan kelompok yang telah ditentukan oleh peneliti. Secara keseluruhan berdasarkan hasil pengamatan yang dilakukan peneliti pada saat siswa belajar kelompok termasuk dalam kategori baik. Sedangkan Hasil Observasi Aktivitas Guru, guru berusaha menerapkan komponen-komponen talking chips dalam pembelajaran materi Lambang Romawi, guru membagi siswa dalam beberapa kelompok dan mengamati aktivitas siswa dalam kelas. Selama kegiatan pembelajaran berlangsung. Dari tabel lembar pengamatan proses belajar mengajar dengan model pembelajaran kooperatif tipe talking chips di atas dapat dilihat bahwa keseluruhan kegiatan-kegiatan yang dilakukan guru pada kegiatan belajar mrngajar seluruhnya terlaksana.

\section{Uji Validitas Instrumen}

Perhitungan uji validitas instrumen tes dilakukan dengan menggunakan rumus korelasi product moment. Pengujian menggunakan taraf signifikasi 0,05 dan hasil di bandingkan dengan $r$ tabel product moment. Kriteria pengujian adalah jika $r_{\text {hitung }}>r_{\text {tabel }}$, maka instrumen atau item-item soal berkorelasi tidak signifikan terhadap skor total (dinyatakan tidak valid). Dalam hal tersebut berikut $r_{\text {tabel }}$ dengan n-2 $=26-2=24$ dan signifikansi 5\% adalah $r_{\text {tabel }}=0,361$. Soal tes siswa yang berjumlah 10 butir terdapat 10 butir yang memenuhi kriteria validitas. Dari sejumlah keseluruhan butir soal, peneliti menggunakan butir soal yang valid untuk penelitian, sedangkan butir soal yang tidak valid tidak dipakai.

\section{Uji Reliabelitas}

Reliabelitas adalah suatu ukuran yang menunjukan sejauh mana hasil pengukuran tetap konsisten bilan diukur beberapa kali dengan alat ukur yang sama. Suatu instrumen dinyatakan reliabel apabila $r_{\text {hitung }}>r_{\text {indeks reliabelitas, }}$ yaitu $r_{\text {hitung }}>0,361$. Pada penelitian ini akan dilakukan uji reliabelitas pada hasil belajar matematika menggunakan perhitungan reliabelitas sebagai berikut.

$$
\begin{aligned}
r_{11}= & \left(\frac{n}{(n-1)}\right)\left(1-\frac{\sum \sigma_{i}^{2}}{\sigma_{t}^{2}}\right) \\
r_{11} & =\left(\frac{10}{10-1}\right)\left(1-\frac{5,23}{22,90}\right. \\
& =\frac{10}{9} \times(1-0,228) \\
& =1,11 \times 0,78=0,86
\end{aligned}
$$


Pernyataan tersebut menunjukan $r_{\text {hitung }}>0,361$ atau $0,86>0,361$ melalui nilai tersebut maka dapat dinyatakan $r$ hitung lebih tinggi dari pada $r$ indeks oleh karena itu instrumen yang digunakan terealibilitas atau reliabel.

\section{Uji Tingkat Kesukaran}

Pengujian taraf kesukaran bertujuan untuk mengetahui tingkat mudah atau sukarnya. Soal terlalu mudah tidak merangsang siswa untuk mempertinggi usaha memecahkannya dan soal yang terlalu sukar akan menyebabkan siswa menjadi putus asa dan tidak mempunyai semangat untuk mencoba lagi karena diluar jangkaunnya. Pengujian taraf kesukaran dalam penelitian dihitung secara manual. Hasil perhitungan tingkat kesukaran soal dapat dilihat bahwa 3 soal sukar, 3 soal sedang, dan 4 soal mudah . dari hasil tersebut dapat disimpulkan bahwa tingkat kesukaran soal berada dalam kategori soal sedang yang artinya soal-soal dianggap baik.

\section{Uji Daya Beda}

Daya beda soal adalah kemampuan suatu soal untuk membedakan anatara siswa yang berkemampuan rendah, dapat dilihat terdapat 3 soal yang dianggap jelek, 4 soal yang dianggap cukup dan 3 soal yang dianggap baik. Dari hasil perhitungan diatas dapat disimpulkan bahwa soal berada dalam uji daya beda di kategori soal cukup dan dianggap sebagai kategori cukup pula dalam hasil penelitian karena butir-butir soal yang cukup baik adalah butir-butir soal yang mempunyai indeks 0,2 sampai dengan 0,4.

\section{Hasil Analisis Statistik Deskriptif}

Berdasarkan tes hasil belajar siswa pada kelas IV SDN 240 Baddo-Baddo Kabupaten Maros yang telah menggunakan model pembelajaran talking chips dengan menggunakan pretest dan posttest maka diperoleh hasil analisis statistik deskriptif sebagai berikut.

Tabel 6.1 Data hasil belajar siswa pretes dan posttest

\begin{tabular}{ccc}
\hline Statistik Deskriptif & Pretest & Posttest \\
\hline Banyaknnya Sampel & 26 & 26 \\
Mean (Rata-Rata) & 55,23 & 72,53 \\
Median (nilai tengah) & 53 & 73 \\
Standar Deviasi & 202,141 & 307,975 \\
Nilai Minimum & 33 & 53 \\
Nilai Maksimum & 80 & 93 \\
Varian & 449,600 & 554,954 \\
\hline
\end{tabular}

Pada tabel 6.1 dapat dilihat hasil belajar matematika materi lambang bilangan romawi pada siswa kelas IV SDN 240 Baddo-Baddo Kabupaten Maros. Bahwa nilai tertinggi untuk prettest adalah 80 dan 93 untuk posttest, nilai terendah pretest yaitu 33 dan untuk posttest nilai terendah yaitu 53. Sedangkan nilai rata-rata pretest 55,23 da nilai rata-rata posttest yaitu 72,53 . Hal ini menunjukan bahwa perolehan hasil belajar setelah adanya tindakan lebih tinggi dari sebelum ada tindakan.

Selain itu juga yang menjadikan model pembelajaran talking chips memiliki pengaruh yang dapat dilihat dari hasil analisis pengskoran prettest dan posttest 
Tabel 6.2 Analisis Tingkat Penguasaan Materi Prettest dan Posttest

\begin{tabular}{cccccc}
\hline Skor & $\begin{array}{c}\text { Frekuensi } \\
\text { Pretest }\end{array}$ & $\begin{array}{c}\text { Presentasi } \\
\text { Pretest }\end{array}$ & $\begin{array}{c}\text { Frekuensi } \\
\text { Posttest }\end{array}$ & $\begin{array}{c}\text { Presentasi } \\
\text { Posttest }\end{array}$ & Kategori \\
\hline $85-100$ & 0 & $0 \%$ & 3 & $11,53 \%$ & Sangat Tinggi \\
$65-84$ & 5 & $19,23 \%$ & 18 & $69,23 \%$ & Tinggi \\
$55-64$ & 3 & $11,53 \%$ & 4 & $15,38 \%$ & Sedang \\
$35-54$ & 14 & $53,84 \%$ & 1 & $3,84 \%$ & Rendah \\
$0-34$ & 4 & $15,38 \%$ & 0 & $0 \%$ & Sangat Rendah \\
\hline
\end{tabular}

Berdasarkan tebel 6.2. analisis tingkat penguasaan materi pada pretest dan posttest menunjukkan perbedaan yang sangat signifikan. Pada Kategori sangat tinggi tidak ada sisiwa yang memperoleh nilai sangat tinggi namun meningkat hingga menjadi $11,53 \%$. Pada kategori tinggi dari 19,23\% meningkat menjadi $69,23 \%$. Pada Kategori sedang dari $11,53 \%$ meningkat menjadi $15,38 \%$. Sementara pada kategori rendah dari $53,84 \%$ menurun menjadi 3, 84\%, begitu pula pada kategori sangat rendah dari $15,38 \%$ pada pretest dan pada posttest sudah tidak ada lagi siswa yang memproleh nilai sangat rendah.

\section{Hasil Analisis Statistik Inferensial}

Tekhnik yang digunakan untuk menguji hipotesis penelitian ini adalah statistik inferensial dengan menggunakan uji-t. Uji hipotesis bertujuan untuk membuktikan apakah model pembelajaran koperatif tipe talking chips berpengaruh terhadap pengenalan lambang bilangan romawi materi lambang bilangan romawi pada siswa kelas IV SDN 240 Baddo-Baddo Kabupaten Maros.

Tabel 7.1 Langkah-Langkah Dalam Pengujian Hipotesis

\begin{tabular}{cc}
\hline Hasil Belajar & Nilai \\
\hline Prettest $\left(\boldsymbol{X}^{\mathbf{1}}\right)$ & 1,344 \\
Posttest $\left(\boldsymbol{X}^{\mathbf{2})}\right.$ & 1,886 \\
$\mathrm{~d}=\boldsymbol{X}^{\mathbf{2}}-\boldsymbol{X}^{\mathbf{1}}$ & 542 \\
$\boldsymbol{d}^{\mathbf{2}}$ & 14,271 \\
Md & 20,84 \\
$\boldsymbol{t}_{\text {hitung }}$ & 9,78 \\
$\boldsymbol{t}_{\text {tabel }}$ & 2,064 \\
Taraf signifikan $a$ & 0,05 \\
\hline Dapat dilihat dari tabel 7.1 diatas untuk & mencari $t_{\text {tabel }}$ peneliti
\end{tabular}
menggunakan tabel distribusi dengan taraf signifikan $a=0,05$ dan $\mathrm{d}, \mathrm{b}=\mathrm{n}-2=26$ $-2=24$ maka diperoleh $t_{0,05}=2,064$. Setelah diperoleh $t_{\text {Hitung }}=9,78$ dan $t_{\text {tabel }}$ $=2,064$ maka diperoleh $t_{\text {hitung }} \geq t_{\text {tabel }}$ atau 9,78 $\geq 2,064$, sehingga dapat disimpulkan bahwa $H_{0}$ ditolak dan $H_{\text {a }}$ diterima. Hal ini berarti pengenalan lambang bilangan romawi setelah diajar dengan model pembelajaran kooperatif tipe talking chips berpengaruh dibandingkan sebelumnya diajar dengan model 
pembelajaran talking chips pada kelas IV SDN 240 Baddo-Baddo Kabupaten Maros.

\section{b. Pembahasan}

Penelitian ini dilakukan sebagai upaya mengetahui pengaruh penerapan model pembelajaran kooperatif tipe talking chips terhadap pengenalan lambang bilangan romawi pada siswa kelas IV SDN 240 Baddo-Baddo Kabupaten Maros.

Secara garis besar, kegiatan dalam penelitian ini dibagi menjadi tiga kegiatan yaitu kegiatan pendahuluan, kegiatan inti, dan kegiatan penutup. Dalam kegiatan pendahuluan peneliti menyampaikan tujuan pembelajaran apersepsi, dan menyajikan informasi. Kegiatan inti peneliti melaksanakan kegiatan belajar mengajar dengan penerapan model pembelajaran kooperatif tipe talking chips. Sedangkan pada kegiatan penutup, peneliti bersama siswa menyimpulkan materi pembelajaran, kemudian siswa mengerjakan soal posttest.

Berikut ini langkah-langkah model pembelajaran kooperatif tipe talking chips yang diterapkan dalam penelitian ini.

a. Guru menyiapkan satu kotak kecil yang berisi kartu kosong

b. Guru membagi siswa dalam beberapa kelompok

c. Sebelum memulai tugasnya, masing-masing anggota dari setiap kelompok mendapatkan 10 kartu kosong

d. Setelah itu, setiap kali siswa ingin berbicara atau mengeluarkan pendapatnya, mereka harus memperlihatkan kartu tersebut yang sudah berisi jawaban dan meletakan kartu tersebut ditengah-tengah meja kelompok atau meja guru

e. Jika kartu yang dimiliki salah satu kelompok habis, maka mereka tidak boleh berbicara lagi sampai semua kelompok mengahabiskan kartunya masing-masing

f. Tetapi jika semua kartu sudah habis, sedangkan tugas belum selesai, kelmpok boleh mengambil kesempatan untuk membagi-bagi dan mengulangi prosedurnya kembali.

Selama pelaksanaan kegiatan belajar mengajar, kegiatan-kegiatan tersebut telah dilaksanakan. Hal tersebut dibuktikan dengan dengan siswa yang semula pasif menjadi aktif dalam kegiatan belajar mengajar dengan penerapan model pembelajaran kooperatif tipe talking chips. Dari hasil observasi menunjukan bahwa siswa yang antusias dalam mengikuti pembelajaran; siswa yang aktif dalam bertanya, berkomentar dan menanggapi; siswa yang aktif dalam kerja kelompok; sikap siswa ketika belajar; serta sikap siswa dalam mengerjakan soal tes termasuk dalam kategori baik.

Dari hasil analisis statistik deskriptif, diketahui bahwa rata-rata hasil belajar siswa untuk nilai pretest yaitu 55,23 dengan standar deviasi 449,600 sedangkan rata-rata untuk nilai posttest yaitu 72,53 dengan standar deviasi yaitu 554,954 dan diketahui selisih nilai sebesar 17,3. Dengan demikian, nilai rata-rata pada posttest lebih tinggi dibanding dengan nilai rata-rata pada pretest. Dari hasil analisis tampak pengaruh penerapan model pembelajaran kooperatif tipe talking chips terhadap materi lambang bilangan romawi pada siswa kelas IV SDN 240 Baddo-Baddo Kabupaten Maros. 
Terdapat pengaruh yang signifikan dari penerapan model pembelajaran kooperatif tipe talking chips terhadap pengenalan lambang bilangan romawi pada siswa kelas IV SDN 240 Baddo-Baddo Kabupaten Maros, hal ini dibuktikan dengan hasil dari pengujian hipotesis dengan menggunakan uji "t" diketahui bahwa nilai dari $t_{\text {tabel }} 2,064 \leq$ dari $t_{\text {hitung }}$ senilai $9,78 \leq$ dari $t_{\text {tabel }}=2,064$

Model pembelajaran kooperatif tipe talking chips ini dapat meningkatkan ketidaksekawanan sosial, memudahkan siswa untuk melakukan penyesuaian sosial, menghilangkan sifat mementingkan diri sendiri atau egois, mementingkan rasa saling percaya, meningkatkan kesediaan menggunakan ide orang lain yang dirasa lebih baik.selain itu model pembelajaran ini memposisikan siswa sebagai manusia yang memiliki pengetahuan lewat pengalaman hidupnya, sehingga dalam menerima informasi tidak hanya dari guru melainkan lingkungan yang memiliki suatu peran besar dalam membentuk kepribadian siswa.

\section{KESIMPULAN}

Hasil peneliti mengenai pengaruh penerapan model pembelajaran kooperatif tipe talking chips terhadap pengenalan lambang bilangan romawi pada siswa kelas IV SDN 240 Baddo-Baddo Kabupaten Maros, dapat penulis simpulkan bahwa terdapat pengaruh penerapan-penerapan model pembelajaran kooperatif tipe talking chips terhadap pengenalan lambang bilangan romawi pada siswa kelas IV SDN 240 Baddo-Baddo Kabupaten Maros. Hal ini dapat dibuktikan dari hasil analisis statistik deskriptif, diketahui bahwa rata-rata hasil belajar siswa untuk nilai pretest yaitu 55,23 mengalami peningkatan pada rata-rata nilai posttest yaitu 72,53 Pada hasil observasi aktivitas siswa termasuk baik dan hasil observasi guru menunjukan keseluruhan dari kegiatan pada proses belajar mengajar yang dinilai pada saat observasi terlaksana semua. Dari hasil analisis statistik inferensial melalui uji " $\mathrm{t}$ " diperoleh nilai dari $t_{\text {tabel }}$ sebesar 2,064 lebih kecil dari $t_{\text {hitung }}$ sebesar 9,78 dengan taraf signifikasi 0,05. Sehingga dapat dikatakan $H_{a}$ diterima dan $H_{\mathrm{o}}$ ditolak. Hal ini berarti model pembelajaran talking chips berpengaruh terhadap hasil belajar.

\section{DAFTAR PUSTAKA}

Ali, Mohammad.(1993).Strategi Penelitian Pendidikan. Bandung:Angkasa.

Arends.(2013).Model Pembelajaran. (Online). Diglib.unila.ac.id. Diakses 12 Maret 2019.

Asdam, Muhhammad. (2013). Strategi Belajar Mengajar. Makassar:LIPa.

Djamarah, Syaiful Bahri dan Aswan Zain. 2010. Strategi Belajar Mengajar. Jakarta:Rineka Cipta.

Hayati, Tuti. (2012). Peningkatan Hasil Belajar Siswa Pada Mata Pelajaran PKn dengan Menggunakan Model Pembelajaran Talking Chips kelas III MIS Tarbiyatul Falah Kaunggading Pamijahan Bogor. Bogor: Universitas Islam Negeri. Skripsi.(Online). Repository.uinjkt.ac.id. Di akses 10 Maret 2013.

Huda, Mifathul. (2011). Cooperative Learning. Celeban Timur : Pustaka Pelajar. 
Isjoni. (2010). Cooperative Learning: Efektivitas pembelajaran kelompok. Bandung: Alfabeta.

Iskandarwassid. Sunendar, Dadang. (2013). Strategi Pembelajaran Bahasa Bandung Rosda.

Jihad dan Haris, (2012). Evaluasi Pembelajaran. Yogjakarta: Multi Pressindo.

Lie, Anita. (2008). Cooperative Learning. Jakarta : Kencana.

Nasiruudin, F. A. Z., \& Hayati, H. (2019). Analisis Kesulitan Menyelesaikan Soal Operasi Hitung Pecahan Pada Siswa Sekolah Dasar Di Makassar. Klasikal: Journal Of Education, Language Teaching And Science, 1(2), 23-31.

Muldayanti. (2013). Pembelajaran Biologi Model STAD dan TGT Ditinjau Dari Keingintahuan Dan Minat Belajar Siswa; Jurnal Pendidikan IPA Indonesia.

M. Thobroni. (2017). Belajar \& pembelajaran. Yogyakarta:Ar-Ruzz Media.

Oktaviana, R. (2014). Implementattion Of Coperative Learning with Talking Chips Technique.On Solids Material. Proce Of International Conference On Research; (Online). Jurnal Pendidikan IPA Indonesia.

Rusman, (2013). Belajar dan Pembelaaran Berbasis Komputer. Bandung: Alfabeta.

Sardiman, A.M. (2004). Interaksi \& Motivasi Belajar Mengajar. Jakarta: PT Raja Grafindo Persada.

Sardiman. (2014).Interaksi dan Motivasi Belajar Mengajar. Jakarta: Rajawali.

Sari, Indah Komala. (2011). Upaya Peningkatan Hasil Belajar Siswa dengan menggunakan model pembelajaran talking chips pada mata Pelajaran IPA Kelas VIII Madrasah Tsanawiyah Miftahussudur Cibuntu Ciampea Bogor. Bogor: Universitas Islam Negeri. Skripsi. (Online). Repository.uinjkt.ac.id. Di akses 10 Maret 2013.

Sugiyono. (2018). Metode Penelitian Kuantitatif, Kualitatif, R\&D. Bandung: Alfabeta.

Suprihatiningrum, Jamil. (2017). Strategi Pembelajaran Teori dan Aplikasi. Jogjakarta; Ar-Ruzz Media.

Suprijono, Agus. (2009). Cooperative Learning. Teori dan Aplikasi PIKEM Jogjakarta:Pustaka Belajar.

Trianto, (2015). Model Pembelajaran. Yogyakarta: Parama Ilmu Waliman, Lim.2007.Problematika Pendidikan Dasar.Bandung:SPs-Upi

Zulfikar. (2016). Pengantar pasar Modal dengan pendekatan statistik. Yogjakarta; Budiu 